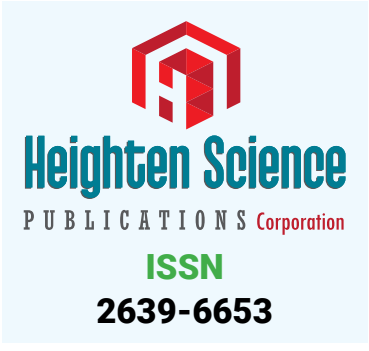

*Address for Correspondence: Dr. Cristian D Merchan, Pharm.D, BCCCP, Critical Care Pharmacotherapist, Department of Pharmacy, New York University Langone Medical Center, New York, USA, Tel: 516-263-1671; Email:

Cristian.Merchan@nyumc.org

Submitted: 25 October 2016

Approved: 15 December 2016

Published: 17 December 2016

Copyright: @2 2016 Merchan et al. This is an open access article distributed under the Creative Commons Attribution License, which permits unrestricted use, distribution, and reproduction in any medium, provided the original work is properly cited.

Keywords: Nootropic; GABA agonist; Drug of abuse; Dietary supplement; Alternative medicine
Case Report

\section{Phenibut Overdose in Combination with Fasoracetam: Emerging Drugs of Abuse}

\author{
Cristian Merchan ${ }^{1 *}$, Ryan Morgan ${ }^{1}$, John Papadopoulos ${ }^{1,2}$ and \\ David Fridman ${ }^{2}$ \\ 'Department of Pharmacy, New York University Langone Medical Center, New York, USA \\ ${ }^{2}$ New York University School of Medicine, New York, USA
}

\section{INTRODUCTION}

The widespread availability of non-traditional dietary supplements and pharmacologically active substances via the Internet continues to introduce mechanisms for inadvertent toxidromes not commonly seen. Consumers are virtually unrestricted in their ability to acquire products purporting augmentation of normal physiology for the purposes of enhancement, recreation, and/or potential abuse. The safety profiles at standard or toxic doses remain largely unknown for many agents that can be purchased electronically. We report a case of mixed toxicity related to phenibut and fosaracetam, both of which are readily available for consumer purchase from online retailers. Written and verbal consent was obtained for this case presentation.

\section{CASE REPORT}

A 27-year-old male with a past medical history of anxiety was discovered unresponsive on the sidewalk. Paramedics responding to the scene noted that the patient had an initial Glascow Coma Score (GCS) of 3 and possessed an empty 5 gram bottle of fasoracetam. During transport to our institution, there were brief periods of severe agitation with emesis. On arrival to our emergency department (ED), the patient exhibited intermittent episodes of agitation and disorientation only upon physical stimulation. Physical exam revealed unremarkable respiratory, abdominal, and musculoskeletal systems. Notably, there were no abnormal pupillary changes or clonus. His vital signs were characterized by normal blood pressure of 135/62 mm Hg, respiratory rate of 12 breaths/min, and an oxygen saturation of $95 \%$ on room air. The most significant finding was a sinus bradycardia with a heart rate of 36 beats/min, for which the patient received $0.5 \mathrm{mg}$ atropine sulfate resulting in a short-lived response to 70 beats/min. All laboratory measurements were within normal limits. Levels for acetaminophen, digoxin, salicylate, and ethanol were not detected. Bedside urine toxicology immunoassay was negative for benzodiazepines, tricyclic antidepressants, cocaine, amphetamines, tetrahydrocannabinol, opioids, barbiturates, phencyclidine and ketamine. A non-contrast CT head ruled out any contributing intracranial pathology.

While in the ED, the patient remained somnolent, and persistently bradycardic with heart rates ranging from 34 to 50 beats/min requiring placement of transcutaneous pacing pads. The patient displayed amnesia to all events preceding his presentation. 
He acknowledged that his current state deviated from his normal baseline neurologic and functional status. The patient denied any recent illicit, prescription, or over-the counter drug use, reported social alcohol consumption, and recent use of fasoracetam to enhance mental capacitance and alertness.

After 24 hours, the patient was able to recall that he purchased phenibut $99.5 \%$ powder 100 grams, and fasoracetam powder 5 grams through LiftMode and Nootropics Depot with the intention to stabilize his 'GABA system'. Two days prior to admission, he was taking phenibut 500mg three times a day and fasoracetam 50-100mg daily. On presentation, he reported that he went to a party and took 10 grams of phenibut and an unknown amount of fasoracetam. On hospital day 2, his lethargy and bradycardia was mostly resolved but complained about increasing anxiety, hallucinations, and delusions of grandeur. He was evaluated by the psychiatric team, and was admitted to the psychiatric unit for evaluation and management of his underlying psychosis.

\section{DISCUSSION}

Racemic phenibut is a GABAB agonist that possesses anxiolytic and nootropic activity mainly attributed to its R-enantiomer [1]. It is structurally similar to baclofen but differs by the presence of one chlorine atom in the benzene ring and is 30 times less active as a GABAB agonist [2]. Other pharmacological activity includes decreasing the activity of voltage-dependent $\mathrm{Ca}^{2+}$ ionic channels similarly to gabapentin and possibly GABAA agonism at high doses [1,2]. Limited information is available on the pharmacokinetics of phenibut. After systemic absorption, phenibut is rapidly distributed to the brain, kidneys, liver, and urine. The elimination half life is 5.3 hours and $65 \%$ of the parent drug is excreted into the urine $[1,2]$.

All published acute toxicities from phenibut are summarized in Table 1 [3-9]. Oral administration of phenibut was the most common route with doses ranging from 1 gram to 30 grams with single oral administration. The onset of desired effects was reported to occur within 2-4 hours following oral ingestion with an overall duration of 7-24 hours. Most patients presented with altered mental status, low levels of consciousness, and agitation upon arousal. In cases characterized by severe agitation, benzodiazepines and antipsychotics demonstrated minimal to moderate effects. All patients were carefully monitored in either an emergency observation or intensive care unit and most were discharged within 24-48 hours from admission.

In contrast to previously reported cases, our patient was also taking fasoracetam which stimulates metabotropic glutamate receptors, up-regulates GABAB receptors, and stimulates the release of acetylcholine from central cholinergic neurons [10]. It is absorbed rapidly after oral administration and has a bioavailability of $79 \%-97 \%$. The elimination half-life ranges from 4-6.5 hours and is predominately excreted in the urine as unchanged drug [10]. Fasoracetam $\left(\mathrm{NFC}^{-1}\right)$ has recently obtained an Investigational New Drug (IND) from the Food and Drug Administration to be evaluated in patients with ADHD who have rare glutamate gene mutation and has a well-established safety profile from previous clinical trials at recommended doses (50-800mg a day in divided doses) [10]. The most commonly reported side effects include headache and fatigue. Nevertheless, large doses of fasoracetam could potentially explain the bradycardia experienced by this patient as it is not seen with the reported cases of phenibut overdoses. In addition, fasoracetam could potentially enhance the response to phenibut through the up-regulation of GABAB receptors and decrease the threshold for tolerance that is commonly observed with phenibut.

Phenibut and fasoracetam are widely available from internet sites that are mainly based in the UK and USA $[2,8]$. These unregulated products place the general public at risk from overdoses and can produce unique toxidromes especially with co-administration of multiple supplements. The clinical management is primarily 
Table 1: Published case reports of phenibut toxicity.

\begin{tabular}{|c|c|c|c|c|c|c|}
\hline $\begin{array}{l}\text { Case } \\
\text { number }\end{array}$ & $\begin{array}{l}\text { Age }+ \\
\text { sex }\end{array}$ & Presenting symptoms & $\begin{array}{l}\text { Comorbidi- } \\
\text { ties }\end{array}$ & $\begin{array}{l}\text { Phenibut expo- } \\
\text { sure }\end{array}$ & $\begin{array}{l}\text { Concomi- } \\
\text { tant medi- } \\
\text { cations }\end{array}$ & Treatment course/outcomes \\
\hline 13 & $20 \mathrm{~F}$ & $\begin{array}{l}\text { Sedated but delirious } \\
\text { when roused }\end{array}$ & NR & $\begin{array}{l}25 \text { grams over } \\
24 \mathrm{~h}\end{array}$ & NR & $\begin{array}{l}\text { - Admitted to ED observation } \\
\text { - GCS increased to } 15 \text { over the next } 12 \mathrm{~h} \\
\text { - Discharged } 24 \text { hours after admission }\end{array}$ \\
\hline 23 & $38 \mathrm{M}$ & Agitated delirium & NR & NR & $\begin{array}{l}\text { Alcohol } \\
\text { and can- } \\
\text { nabis }\end{array}$ & $\begin{array}{l}\text { - Droperidol } 10 \mathrm{mg} \mathrm{IM} \times 2 \text { doses with no effect on sedation } \\
\text { - Ketamine } 4 \mathrm{mg} / \mathrm{kg} \text { IM was used successfully } \\
\text { - After } 2.5 \mathrm{~h} \text { the patient was agitated and decision was made to } \\
\text { intubate in order to protect airway } \\
\text { - Admitted to ICU, sedation was managed with morphine, mid- } \\
\text { azolam and propofol } \\
\text { - Extubated after } 15 \text { hours } \\
\text { - Discharged from hospital }\end{array}$ \\
\hline 34 & NR & $\begin{array}{l}\text { Agitated, hyperther- } \\
\text { mia, tachycardia }\end{array}$ & NR & 1 gram & NR & NR \\
\hline 44 & NR & $\begin{array}{l}\text { Agitated and abdomi- } \\
\text { nal pain }\end{array}$ & NR & $\begin{array}{l}7.5-10 \text { grams in a } \\
\text { suicide attempt. }\end{array}$ & NR & - Gastric lavage and activated charcoal 45 minutes after intake \\
\hline 54 & M & Tremors and dysuria & NR & $\begin{array}{l}10-15 \text { grams daily } \\
\text { during } 3 \text { months. }\end{array}$ & NR & NR \\
\hline 64 & NR & $\begin{array}{l}\text { Agitation, mydriasis } \\
\text { and seizures }\end{array}$ & NR & NR & NR & NR \\
\hline 74 & M & $\begin{array}{l}\text { Loss of conscious- } \\
\text { ness }\end{array}$ & NR & $\begin{array}{l}10 \text { grams daily } \\
\text { over several days }\end{array}$ & NR & $\begin{array}{l}\text { - Discharge from the hospital, he continued using phenibut, and } 3 \\
\text { days later, he was again admitted with seizures. }\end{array}$ \\
\hline 85 & $33 \mathrm{~F}$ & $\begin{array}{l}\text { Sedation and myo- } \\
\text { clonic jerking }\end{array}$ & $\begin{array}{l}\text { Opioid } \\
\text { abuse }\end{array}$ & NR & NR & - Alertness improved over 7 hours. \\
\hline 95 & $59 \mathrm{~F}$ & $\begin{array}{l}\text { Lethargic and tonic- } \\
\text { clonic seizure } \\
\text { GCS } 11\end{array}$ & $\begin{array}{l}\text { Chronic } \\
\text { pain with } \\
\text { high dose } \\
\text { opioid use }\end{array}$ & NR & NR & $\begin{array}{l}\text { - After } 12 \text { hours she aroused with agitation, hypertension and } \\
\text { tachycardia that was managed with benzodiazepines. }\end{array}$ \\
\hline 105 & $23 \mathrm{M}$ & Lethargic & $\begin{array}{l}\text { Substance } \\
\text { abuse }\end{array}$ & NR & NR & - Aroused after 7 hours \\
\hline 115 & $42 \mathrm{~F}$ & $\begin{array}{l}\text { Altered mental status, } \\
\text { incoherent speech } \\
\text { and incontinence. }\end{array}$ & NR & NR & NR & $\begin{array}{l}\text { - Arousal over several hours was complicated by hallucinations } \\
\text { and agitation requiring benzodiazepines. Symptoms all cleared } \\
\text { within } 24 \text { hours. }\end{array}$ \\
\hline $\begin{array}{l}\text { Retro- } \\
\text { spec- } \\
\text { tive } \\
\text { review } \\
\text { of } 6 \\
\text { cases6 }\end{array}$ & NR & $\begin{array}{l}\text { In all cases agitation } \\
\text { was reported } \\
83 \% \text { confusion } \\
50 \% \text { HTN } \\
33 \% \text { rigidity }\end{array}$ & & $\begin{array}{l}2 / 6 \text { took } 9-9.5 \\
\text { grams } \\
3 / 6 \text { unknown } \\
1 / 610 x \text { usual } \\
\text { dose }\end{array}$ & $\begin{array}{l}50 \% \text { NR } \\
33 \% \text { alco- } \\
\text { hol }\end{array}$ & $\begin{array}{l}\text { - Treatment included benzodiazepines in } 4 \text { of the } 6 \text { exposure } \\
\text { cases with moderate effects }\end{array}$ \\
\hline 127 & $43 \mathrm{M}$ & $\begin{array}{l}\text { Agitation interspersed } \\
\text { with somnolence, } \\
\text { dilated pupils and } \\
\text { dystonias }\end{array}$ & Depression & 30 grams & None & $\begin{array}{l}\text { - 10-mg IM midazolam for his agitation with minimal effect } \\
\text { - Due to ongoing agitation, he was sedated, intubated and moni- } \\
\text { tored in the ICU. } \\
\text { - Extubated the following day with normal vital signs } \\
\text { - Assessed by the psychiatry team and was discharged with com- } \\
\text { munity follow-up. }\end{array}$ \\
\hline 138 & $44 \mathrm{M}$ & $\begin{array}{l}\text { Agitated and con- } \\
\text { fused. } \\
\text { GCS } 12\end{array}$ & & $\begin{array}{l}\text { Regularly took } \\
\text { three teaspoons } \\
\text { ( 500-1500 mg) } \\
\text { of the phenibut } \\
\text { powder. Due to } \\
\text { increasing toler- } \\
\text { ance on the day } \\
\text { of admission, } \\
\text { he took one big } \\
\text { tablespoon the } \\
\text { night before. }\end{array}$ & None & $\begin{array}{l}\text { - Despite de-escalation and repeated dose of oxazepam and mid- } \\
\text { azolam, he became increasingly uncooperative. } \\
\text { - Subsequently intubated and sedated with midazolam, propofol } \\
\text { and rocuronium. } \\
\text { - Post intubation was complicated with an MRSA PNA } \\
\text { - Extubated after } 72 \text { hours } \\
\text { - After } 96 \text { hours, started to withdrawal with increasing headache } \\
\text { and anxiety } \\
\text { - Was eventually discharged home }\end{array}$ \\
\hline 14 & $25 \mathrm{M}$ & $\begin{array}{l}\text { Unconscious and } \\
\text { minimally responsive. }\end{array}$ & $\begin{array}{l}\text { Ethanol de- } \\
\text { pendence }\end{array}$ & $\begin{array}{l}1.5 \text { grams twice } \\
\text { daily for } 4 \text { days }\end{array}$ & Alcohol & $\begin{array}{l}\text { - Over the next } 7 \text { hours the patient slowly returned to a normal } \\
\text { level of consciousness. }\end{array}$ \\
\hline
\end{tabular}

$N R=$ not reported, $P N A=$ pneumonia 
supportive, but should incorporate a thorough history of recent medication use, including dietary supplements and vitamins. In the majority of phenibut overdoses, the toxicological properties predominantly effects the central nervous system and to a lesser extent the cardiovascular system. Healthcare providers should be prepared to manage or inform patients about the acute excess or withdrawal side effects after phenibut or fasoracetam overdoses [11].

\section{REFERENCES}

1. Lapin I. Phenibut (beta-phenyl-GABA) a tranquilizer and nootropic drug. CNS Drug Rev. 2001; 7: 471-481. Ref.: https://goo.gl/cbWDei

2. Owen DR, Wood DM, Archer JRH, Dargan PI. Phenibut (4-amino-3-phenyl-butyric acid): Availability, prevalence of use, desired effects and acute toxicity. Drug Alcohol Rev. 2016; 35:591-596. Ref.: https://goo.gl/339Apv

3. Downes MA, Berling IL, Mostafa A, Grice J, Roberts MS, Isbister GK, et al. Acute behavioural disturbance associated with phenibut purchased via an internet supplier. Clin Toxicol (Phila). 2015; 53: 636-638. Ref.: https://goo.gl/54dXnR

4. Koppen A, Van Riel A, Roelen C, Meulenbelt J. Reports of phenibut usage to the dutch poisons information center (DPIC). Clin Toxicol (Phila). 2015; 53: 716-717.

5. Marraffa JM, Nacca NE, Stork CM, Hodgman MJ. Phenibut: one poison center's experience. Clin Toxicol (Phila). 2014; 52: 764.

6. Goertemoeller S, Behrman A, Goetz R, Spiller H. Retrospective review of Phenibut exposures reported to Ohio poison control centers. Clin Toxicol (Phila). 2015; 53: 736-737.

7. Wong A, Little M, Caldicott D, Easton C, Andres D, Greene SL, et al. Analytically confirmed recreational use of phenibut (beta- phenyl-gamma-aminobutyric acid) bought over the internet. Clin Toxicol (Phila). 2015; 53: 783-784. Ref.: https://goo.gl//11cHM

8. Li CK, Sundararajan K. An Uncommon Case of Phenibut Toxicity in an Intensive Care Unit. IJMPCR. 2015; 5: 1-6. Ref.: https://goo.gl/8RfxCh

9. O'Connell CW, Schneir AB, Hwang JQ, Cantrell FL. Phenibut, the appearance of another potentially dangerous product in the United States. Am J Med. 2014; 127: 3-4. Ref.: https://goo.gl/SJKbH2

10.Malykh AG, Sadie MR. Piracetam and piracetam-like drugs: from basic science to novel clinical applications to CNS disorders. Drugs. 2010; 70: 287-312. Ref.: https://goo.gl/yl9uom

11.Magsalin RM, Khan AY. Withdrawal symptoms after internet purchase of phenibut. J Clin Psychopharmacol. 2010; 30: 648-649. Ref.: https://goo.gl/HnXv5B 